\title{
HUBUNGAN KETERSEDIAAN KOLEKSI DAN KOMPETENSI PUSTAKAWAN DENGAN KEPUASAN PEMUSTAKA
}

\author{
Pebrian*), Yunus Winoto ${ }^{* *}$ ), Encang Saefudin ***) \\ Fakultas Ilmu Komunikasi, Universitas Padjadjaran, Bandung Indonesia \\ E-mail: yunuswinoto@gmail.com
}

Naskah diterima: 5 September; direvisi: 13 September; disetujui: 18 September

\begin{abstract}
Abstrak
Penelitian ini bertujuan untuk megetahui sejauh mana hubungan ketersediaan koleksi dan kompetensi pustakawan dengan kepuasan pemustaka di perpustakaan. Lokasi penelitian adalah perpustakaan Open Library Telkom University. Pada pengukuran kepuasan pemustaka menggunakan teori Expectancy-Disconfirmation Paradigm (EDP) menurut Oliver. Metode yang digunakan adalah metode kuantitatif dengan uji korelasional Pearson Product Moment yang bertujuan untuk menguji hubungan sebab akibat antara variabel X dan Y. Teknik Pengumpulan data dalam penelitian ini dilakukan melalui kuesioner, wawancara, dan studi literatur. Populasi pada penelitian ini sebanyak 27.997 mahasiswa dengan responden berjumlah 100 mahasiswa yang ditentukan menggunakan teknik sampel acak sederhana (simple random sampling). Berdasarkan hasil penelitian ini menunjukkan bahwa ketersediaan koleksi yang terdiri dari aspek relevansi, kelengkapan, kemutakhiran, dan keberagaman, serta kompetensi pustakawan yang terdiri dari aspek professional dan personal terhadap kepuasan pemustaka memiliki hubungan yang kuat dengan nilai $t_{\text {hitung }} 14,52$ dengan $t_{\text {tabel }} 1,66$.
\end{abstract}

Kata Kunci: Ketersediaan koleksi, kompetensi pustakawan, kebutuhan informasi, Open Library.

\begin{abstract}
This study aims to determine the correlation between the availability of collections and the competence of librarians with satisfaction of visitors in the library. The research location is in the Open Library Telkom University. Measurement of user satisfaction is using the theory of Expectancy-Disconfirmation Paradigm (EDP) according to Oliver. The method used is a quantitative method with Pearson Product Moment correlation test which aims to test the causal relationship between variables $X$ and $Y$. Data collection process were conducted through questionnaires, interviews, and literature studies. The population in this study were 27,997 students with total respondents 100 students who were determined using simple random sampling techniques. Based on the results of this study indicate that the availability of collections consisting of aspects of relevance, completeness, sophistication, and diversity, as well as librarian competency consisting of professional and personal aspects of user satisfaction has a strong relationship with tcount 14.52 with ttable 1.66.
\end{abstract}

Keyword: Availability of collections, librarian competencies, information needs, Open Library.

\section{Pendahuluan}

Saat ini manusia telah mengalami berbagai perubahan dalam bidang kehidupan. Salah satu perubahan yang dimaksud yaitu dengan mudahnya sebuah informasi didapat. Perubahan itu timbul akibat tingginya rasa ingin tahu manusia akan sebuah informasi dan tidak ingin manusia tersebut tertinggal sedikitpun untuk mencari sebuah informasi daripada yang lain. Kebutuhan memenuhi informasi oleh manusia didasari oleh sifat alami manusia yang ingin tahu berbagai hal dalam kehidupan. Kebutuhan informasi manusia dibutuhkan sebagai menambah wawasan dan ilmu pengetahuan yang bisa dipakai dan diimplementasikan kepada masayarakat. Kapan dan dimanapun kita berada, 
pastinya membutuhkan sebuah informasi yang disajikan dalam bentuk lisan maupun tulisan. Untuk informasi secara lisan sendiri, bisa didapatkan melalui sebuah percakapan personal maupun berkelompok. Sedangkan untuk informasi tulisan, bisa didapatkan dari berbagai media, salah satunya yaitu perpustakaan.

Perpustakaan merupakan salah satu tempat yang menyediakan informasi. Menurut Basuki (1991:3), istilah perpustakaan yaitu "sebuah ruangan, bagian sebuah gedung, ataupun gedung itu sendiri yang digunakan untuk menyimpan buku dan terbitan lainnya yang biasanya disimpan menurut tata susunan tertentu untuk digunakan pembaca, bukan untuk dijual". Hal tersebut dapat diartikan bahwa perpustakaan merupakan sebuah tempat yang menyediakan informasi dari berbagai koleksi yang tersedia dalam bentuk cetak dan non-cetak serta terdiri dari informasi yang valid dan relevan. Perpustakaan terdiri dari berbagai jenis, salah satunya adalah perpustakaan perguruan tinggi. Perpustakaan perguruan tinggi merupakan salah satu aset informasi bagi perguruan tinggi itu sendiri yang menunjang proses pembelajaran bagi sivitas akademika. Perpustakaan perguruan tinggi bertujuan untuk mengumpulkan, mengolah, menyimpan, menyajikan dan menyebarluaskan informasi untuk mahasiswa dan dosen sesuai dengan kurikulum yang berlaku.

Sebagai media dalam menyampaikan informasi, perpustakaan harus memiliki pustakawan yang bertugas untuk menjalankan fungsi dari perpustakaan. Pustakawan dituntut untuk memiliki keahlian yang tinggi sehingga dapat menjalankan perpustakaan dengan baik. Kompetensi pustawakan sendiri adalah sebuah kemampuan pustawakan secara profesional dan personal dalam menjalankan aktivitas kerja perpustakaan. Kompetensi pustakawan mengharuskan setiap pustakawan bekerja secara optimal dalam setiap bidang pengembangan perpustakaan. Kompetensi pustakawan diharapkan menutupi setiap celah kekurangan perpustakaan yang dampaknya sendiri berupa penilaian pemustaka setelah menggunakan perpustakaan. Biasanya, perpustakaan telah membekalkan setiap pustakawan yang bekerja dalam sebuah pelatihan untuk menambah kompetensi pustakawan tersebut. Setelah proses pelatihan yang didapat, pustakawan dapat meneruskan ilmu pelatihan untuk pengembangan perpustakaan. Semua perpustakaan diwajibkan melakukan pelatihan kepada pustakawannya, tak terkecuali perpustakaan perguruan tinggi.
Pada umumnya di dalam perpustakaan terdapat koleksi untuk digunakan oleh pemustaka. Menurut UU No. 43 Tahun 2007 pasal 1 dan 2 mengatakan bahwa koleksi perpustakaan adalah semua informasi dalam bentuk karya tulis, karya cetak dan karya rekam dalam bentuk berbagai media yang mempunyai nilai pendidikan yang dihimpun, diolah dan dilayankan. Koleksi sendiri merupakan aset penting bagi perpustakaan karena tanpa adanya koleksi, perpustakaan tidak dapat menjalankan fungsinya.

Salah satu kegiatan di perpustakaan adalah pengembangan koleksi. Pengembangan dari kegiatan tersebut adalah ketersediaan kolsi yang telah mengalami tahapan-tahapan guna menghasilkan koleksi yang memenuhi kebutuhan informasi pemustaka. Ketersediaan koleksi perpustakaan sangatlah penting bagi perpustakaan itu sendiri yang merupakan aset dalam mengenalkan identitas perpustakaan tersebut. Berbagai jenis perpustakaan tentunya memiliki ciri khas dalam ketersediaan koleksi. Setiap perpustakaan menunjukkan ketersediaan koleksi dalam jenis perpustakaan.

Pemustaka merupakan salah satu unsur yang terkait dengan perpustakaan. Kepuasan pemustaka menjadi salah satu bagian misi dari setiap perpustakaan manapun. Sebuah pencapaian yang bagus bagi perpustakaan dari beberapa poin yang terpenuhi dalam kepuasan pemustaka tersebut. Beberapa poin kepuasan bisa berupa gedung perpustakaan yang mengikuti design masa kini, layanan perpustakaan yang tidak dimiliki perpustakaan lain, dan alat temu kembali informasi. Akan tetapi dengan salah satu tujuan datang ke perpustakan yaitu untuk memenuhi kebutuhan informasi, ketersediaan koleksi perpustakaan dan pustakawan itu sendiri dapat dijadikan sebagai pemenuhan kebutuhan informasi yang bisa berdampak pada kepuasan pemustaka. Komponen ketersediaan koleksi dan pustakawan bisa menjadi bagian yang andil dalam tujuan adanya perpustakaan.

Perpustakaan Telkom University atau dengan nama lain yaitu Open Library merupakan sebuah perpustakaan perguruan tinggi yang disediakan untuk sivitas akademika Telkom University. Open Library Telkom University merupakan sebuah bagian dari Unit Sumber Daya Keilmuan dan Perpustakaan yang berperan aktif dalam penyediaan dan peningkatan kuaitas sumber-sumber keilmuan dan bahan pustaka baik yang lahir dari civitas akademika maupun 
dari luar Telkom University sehingga sumber daya keilmuan dan bahan pustaka yang dimiliki bisa dimanfaatkan untuk kepentingan pengelolaan institusi serta mendukung pelaksanaan Tri Dharma Perguruan Tinggi yaitu proses belajar mengajar, penelitian dan pengabdian masyarakat.

Berdasarkan hasil pantauan yang peneliti lihat hingga bulan Juli 2018, jumlah koleksi yang tersedia di Open Library berjumlah 123.496 koleksi dari 80.457 judul. Dengan data statistik pengunjung Juli 2018 tercatat berjumlah 5.956 pengunjung, dengan pengunjung untuk jenjang D3 berjumlah 1.150 orang, jenjang D4 berjumlah 16 orang, jenjang S1 berjumlah 3.389 dan jenjang S2 berjumlah 68 orang. Sedangkan dosen/pegawai yang berkunjung ke Open Library berjumlah 696 pengunjung. Sedangkan untuk jumlah pustakawan terhitung dari bulan Juli 2018 sebanyak 10 orang. Terdiri dari pustakawan tetap berjumlah 6 orang pustakawan tidak tetap berjumlah 2 orang, serta 2 orang dalam bidang teknologi informasi (TI) dan teknik komputer.

Dari banyaknya jumlah pemustaka yang datang dan keberagaman koleksi yang tersedia sudah dapat mencukupi kebutuhan informasi pemustaka. Akan tetapi, ada salah satu faktor yang mempengaruhi kurangnya ketersediaan koleksi yang belum dikembalikan pemustaka. Pada data statistik Juli 2018, total peminjaman koleksi berjumlah 313.882 dan jumlah koleksi yang belum dikembalikan oleh pemustaka hingga saat ini berjumlah 1.336 koleksi. Sedangkan untuk bagian kompetensi pustakawan, dengan jumlah pustakawan Open Library yang tetap yaitu berjumlah 8 orang saja adalah kurang dari cukup untuk menjalankan tugas serta pengembangan perpustakaan dan memiliki kompetensi pustakawan. Maka dari itu, dari data tersebut bisa mempengaruhi kepuasan pemustaka terhadap ketersediaan koleksi dan kompetensi pustakawan di Open Library Telkom University.

Berdasarkan uraian di atas, tujuan dari penelitian ini adalah sebagai berikut: 1) Untuk mengetahui hubungan ketersediaan koleksi dengan kepuasan pemustaka di Open Library Telkom University; dan 2) Untuk mengetahui hubungan kompetensi pustakawan dengan kepuasan pemustaka di Open Library Telkom University.

\section{Metode Penelitian}

Pada penelitian ini menggunakan jenis penelitian kuantitatif. Menurut Sugiyono (2014), penelitian kuantitatif merupakan penelitian yang berlandaskan filsafat positivisme, digunakan untuk meneliti pada populasi atau sampel tertentu, pengumpulan data menggunakan instrumen penelitian, analisis data bersifat kuantitatif/statistik, dengan tujuan untuk mengetahui hipotesis yang telah ditetapkan. Sedangkan untuk metode penelitian yang digunakan mengunakan metode korelasi yang bertujuan untuk mengetahui sejauh mana hubungan kepuasan pemustaka dan kompetensi pustakawan dengan ketersediaan koleksi Open Library Telkom University. Uji korelasi pada penelitian ini menggunakan korelasi Pearson Product Moment.

Populasi pada penelitian ini merupakan mahasiswa aktif Telkom University pada jenjang sarjana dan diploma dengan jumlah 27.997 mahasiswa. Data tersebut terhitung per September 2018. Penentuan jumlah sampel menggunakan simple random sampling (probability sampling) sebanyak 100 responden. Pada penelitian ini menggunakan dua jenis data yaitu data primer dan sekunder. Data primer dihasilkan dari kuesioner yang dibagikan kepada responden serta dari hasil wawancara kepada pustakawan Open Library Telkom University. Sedangkan data sekunder berasal dari studi kepustakaan.

Teknik pengumpulan data pada penelitian ini terdiri dari observasi, wawancara, studi kepustakaan, dan kuesioner. Pada penelitian ini kuesioner meruapakan alat pengumpulan data yang utama dengan memberikan pertanyaan dari setiap indikator. Skala yang digunakan menggunakan skala likert yang terdiri dari $1=$ Sangat Tidak Setuju; 2 = Tidak Setuju; 3 = Netral; 4 = Setuju; 5 = Sangat Setuju.

Pada penelitian ini teknik inferensial yang digunakan menggunakan uji korelasi Pearson Product Moment (r). Uji korelasi Pearson Product Moment bertujuan untuk menguji hubungan sebab akibat antara variabel X dan variabel Y. Menurut Prijana, Winoto \& Yanto (2016),

Pearson Product Moment memiliki syarat skala pengukuran statistik yaitu menggunakan skala interval.Pada sebuah analisis korelasi Pearson Product Moment tidak disarankan untuk menggunakan skala ordinal.Namun apabila data yang ada merupakan data ordinal, maka data tersebut harus dinaikan dahulu skalanya dengan $a$ method successive of interval.

Secara sederhana untuk mengetahui kuat atau lemahnya tingkat atau derajat keeratan hubungan antara variabel $\mathrm{X}$ dan $\mathrm{Y}$ dapat 
diterangkan menggunakan tabel interpretasi sebagai berikut:

Tabel Interpretasi Koefisein Korelasi Nilai r

\begin{tabular}{|l|l|}
\hline $\begin{array}{c}\text { Interval } \\
\text { Koefisien }\end{array}$ & \multicolumn{1}{c|}{$\begin{array}{c}\text { Tingkat } \\
\text { Hubungan }\end{array}$} \\
\hline $0,80-1,000$ & Sangat Kuat \\
\hline $0,60-0,799$ & Kuat \\
\hline $0,40-0,599$ & Cukup Kuat \\
\hline $0,20-0,399$ & Rendah \\
\hline $0,00-0,199$ & Sangat Rendah \\
\hline
\end{tabular}

Sumber: Akdon dalam Kirom (2015)

Setelah mendapatkan hasil dari perhitungan uji korelasi pearson product moment, maka dilanjutkan dengan uji signifikan dengan rumus sebagai berikut :

$$
t_{\text {hitung }}=\frac{p \sqrt{n-2}}{\sqrt{1-p^{2}}}
$$

Hasil perhitungan $t_{\text {hitungakan dibandingkan }}$ dengan $t_{\text {tabel. }}$. Apabila hasil $t_{\text {hitung }}>t_{\text {tabel }}$ maka memiliki arti $\mathrm{H} 1$ diterima dan Ho ditolak dan jika $t_{\text {hitung }}<t_{\text {tabel }}$ maka memiliki arti H1 ditolak dan Ho diterima.

\section{Hasil Dan Pembahasan}

3.1 Hubungan antara Ketersediaan Koleksi (X1) dengan Kepuasan Pemustaka (Y) di Open Library Telkom University

Berdasarkan hasil pengujian statistik menggunakan Pearson Product Moment, didapat hasil nilai koefiesien korelasi sebesar 0,761 dengan derajatkepercayaan 90\%. Hal tersebut menunjukkan bahwa keeratan hubungan antara ketersediaan koleksi dengan kepuasa pemustaka di Open Library Telkom University memiliki hubungan kuat. Hasil perhitungan $t_{\text {hitung }}(11,62) \geq$ $t_{\text {tabel }}(1,66)$ yang artinya ketersediaan koleksi berhubungan signifikan dengan kepuasan pemustaka.

Ketersediaan koleksi merupakan hasil dari proses tahapan pengembangan koleksi perpustakaan yang dilakukan secara sistematis agar mendapatkan kualitas koleksi yang baik. Dalam melakukan kegiatan pengembangan koleksi, haruslah memperhatikan prinsip-prinsip pengembangan koleksi yang terdiri dari 4 indikator yaitu relenvansi, kelengkapan, kemutakhiran, dan keragaman. Kegiatan pengembangan koleksi tentunya sangatlah berpengaruh akan adanya kebijakan dari asasasas yang dikemukakan oleh Darmono (dalam Hawalmy 2017) dari segi kualitas dan kuantitas koleksi perpustakaan. Kebijakan tersebut tidak bisa berjalan sendiri tanpa adanya pihak yang berkerjasama dalam membangun perpustakaan bidang pengembangan koleksi untuk ketersediaan koleksi perpustakaan.
Kepuasan pemustaka merupakan sebuah harapan yang dipikirkan oleh pemustaka terhadap berbagai komponen jasa dan fasilitas yang perpustakaan berikan kepada pemustaka. Pihak perpustakaan tentunya harus berusaha maksimal dalam mewujudkan harapan yang sudah terpikirkan sebelum berkunjung ke perpustakaan yang nantinya pemustaka akan tetap setia berkunjung ke perpustakaan. Menurut Irawan (2002: 13) "kepuasan merupakan persepsi orang terhadap produk atau jasa yang telah memenuhi harapannya" atau dengan kata lain kepuasan merupakan harapan seseorang dalam pemikiran akan produk atau jasa terhadap kenyataan yang sebenarnya.

Berdasarkan hasil wawancara dengan salah satu pustakawan Open Library, mengatakan bahwa ketersediaan koleksi di Open Library telah mencapai $90 \%$ dari kebutuhan informasi pemustaka. Ketersediaan koleksi Open Library merupakan hasil dari proses pengembangan koleksi yang dilakukan 1 tahun sekali dengan melibatkan pihak ketiga untuk membantu menjalankan proses pengembangan koleksi. Berdasarkan keterangan yang diperoleh dari salah satu responden, mengatakan bahwa ketersediaan koleksi Open Library sudah lengkap dan memenuhi kebutuhan informasi yang dibutuhkan. Jadi, kesimpulannya adalah Open Library Telkom University telah mampu menjadi perpustakaan perguruan tinggi yang baik dan mampu menjadi perpustakaan yang dibutuhkan oleh mahasiswa Telkom University.

\begin{tabular}{|c|c|c|c|c|}
\hline $\begin{array}{c}\text { Sub } \\
\text { Variabel }\end{array}$ & $\rho$ & $t_{\text {hitung }}$ & $\mathbf{t}_{\text {tabe }}$ & $\underset{n}{\text { Keputusa }}$ \\
\hline Hubungan & \multirow{10}{*}{$\begin{array}{l}0,76 \\
1\end{array}$} & \multirow{10}{*}{$\begin{array}{l}11,6 \\
2\end{array}$} & \multirow{10}{*}{$\begin{array}{l}1,6 \\
6\end{array}$} & \multirow{10}{*}{$\begin{array}{l}\mathrm{H}_{1} \\
\text { Diterima }\end{array}$} \\
\hline Ketersediaa & & & & \\
\hline n Koleksi & & & & \\
\hline dengan & & & & \\
\hline Kepuasan & & & & \\
\hline Pemustaka & & & & \\
\hline di Open & & & & \\
\hline Library & & & & \\
\hline Telkom & & & & \\
\hline University & & & & \\
\hline
\end{tabular}

\subsection{Hubungan antara Kompetensi Pustakawan (X2) dengan Kepuasan Pemustaka (Y) di Open Library Telkom University \\ Berdasarkan hasil pengujian statistik} menggunakan Pearson Product Moment, didapat hasil nilai koefiesien korelasi sebesar 0,769 dengan derajat kepercayaan 90\%. Hal tersebut menunjukkan bahwa keeratan hubungan antara kompetensi pustakawan dengan kepuasa pemustaka di Open Library Telkom University memiliki hubungan kuat. Hasil perhitungan $t_{\text {hitung }}$ 
$(11,91) \geq t_{\text {tabel }}(1,66)$ yang artinya kompetensi pustakawan berhubungan signifikan dengan kepuasan pemustaka.

Kompetensi pustakawan merupakan kinerja dan kemampuan pustakawan dalam pelaksanaan tugas jabatannya. Kompetensi pustakawan mendapatkan nilai ketika seorang pustakawan memiliki keterampilan khusus dalam pekerjaannya. Setiap perpustakaan memiliki standarisasi pustakawan, sebagaimana Peraturan Pemerintah Nomor 24 Tahun 2014 tentang Pelaksanaan Undang-undang Nomor 43 Tahun 2007 tentang Perpustakaan, Pasal 34 menyatakan bahwa pustakawan harus memiliki (1) kompetensi profesional dan (2) kompetensi personal. Kompetensi profesional sendiri mencakup aspek pengetahuan, keahlian dan sikap kerja. Sedangkan, kompetensi personal mencakup aspek kepribadian dan interaksi sosial.

Kepuasan pemustaka merupakan sebuah harapan yang dipikirkan oleh pemustaka terhadap berbagai komponen jasa dan fasilitas yang perpustakaan berikan kepada pemustaka. Pihak perpustakaan tentunya harus berusaha maksimal dalam mewujudkan harapan yang sudah terpikirkan sebelum berkunjung ke perpustakaan yang nantinya pemustaka akan tetap setia berkunjung ke perpustakaan. Menurut Irawan (2002: 13) "kepuasan merupakan persepsi orang terhadap produk atau jasa yang telah memenuhi harapannya" atau dengan kata lain kepuasan merupakan harapan seseorang dalam pemikiran akan produk atau jasa terhadap kenyataan yang sebenarnya.

Berdasarkan hasil wawancara dengan salah satu pustakwan Open Library, yang mengatakan bahwa saat ini jumlah pustakawan tetap Open Library berjumlah 6 orang dan semuanya mempunyai jenjang pendidikan terakhir ilmu perpustakaan, 2 staf perpustakaan pembantu yaitu pada bidang Teknik Informatika dan Teknik Komputer. Berdasarkan keterangan yang diperoleh dari salah satu responden yang berkunjung ke Open Library, yang mengatakan bahwa pustakawan yang mempunyai jenjang pendidikan terakhir ilmu perpustakaan, memiliki pengetahuan lebih dalam mengenai masalah internal-eksternal yang ada di perpustakaan. Pada nantinya, pengetahuan tersebut akan berdampak pada kualitas perpustakaan yang baik dan nilai tambah pustakawan dimata pemustaka. Nilai tambah tersebut akan menjadi sebuah kepuasan pemustaka sendiri setelah memakai jasa pustakawan perpustakaan.

\begin{tabular}{|l|l|l|l|l|}
\hline $\begin{array}{l}\text { Sub } \\
\text { Variabel }\end{array}$ & $\boldsymbol{\rho}$ & $\mathbf{t}_{\text {hitung }}$ & $\begin{array}{l}\mathbf{t}_{\text {tabe }} \\
\mathbf{l}\end{array}$ & $\begin{array}{l}\text { Keputusa } \\
\mathbf{n}\end{array}$ \\
\hline $\begin{array}{l}\text { Hubungan } \\
\text { Kompetensi }\end{array}$ & 0,76 & 11,9 & 1,66 & $\mathrm{H}_{1}$ \\
$\begin{array}{l}\text { Pustakawa } \\
\text { n dengan }\end{array}$ & & 1 & & Diterima \\
Kepuasan \\
$\begin{array}{l}\text { Pemustaka } \\
\text { di Open }\end{array}$ & & & & \\
Library & & & & \\
Telkom & & & & \\
University & & & & \\
\hline
\end{tabular}

3.3 Hubungan Ketersediaan Koleksi (X1) dan Kompetensi Pustakawan (X2) dengan kepuasan Pemustaka (Y) di Open Library Telkom University

Berdasarkan hasil pengujian statistik menggunakan Pearson Product Moment, didapat hasil nilai koefiesien korelasi sebesar 0,826 dengan derajat kepercayaan $90 \%$. Hal tersebut menunjukkan bahwa keeratan hubungan ketersediaan koleksi dan kompetensi pustakawan dengan kepuasan pemustaka di Open Library Telkom University memiliki hubungan kuat. Hasil perhitungan $t_{\text {hitung }}(14,52) \geq$ $t_{\text {tabel }}(1,66)$ yang artinya ketersediaan koleksi dan kompetensi pustakawan berhubungan signifikan dengan kepuasan pemustaka.

Kepuasan pemustaka merupakan suatu harapan pemustaka akan kenyataan keadaan fasilitas dan layanan yang tersedia di perpustakaan. Kepuasan pemustaka sendiri merupakan nilai penting bagi perpustakaan untuk menambah kualitas citra perpustakaan itu sendiri. Perpustakaan senantiasa memberikan pelayanan terbaik bagi pemustaka yang datang ke perpustakaan dengan menyediakan aspek fasilitas dan jasa perpustakaan, yang tak lain yaitu ketersediaan koleksi perpustakaan dan kompetensi pustakawan.

Ketersediaan koleksi Open Library telah mencakupi aspek kebijakan pengembangan koleksi yaitu relevansi, kelengkapan, kemutakhiran, dan keragaman. Open Library telah menjalankan kegiatan pengembangan koleksi berdasarkan tahapan-tahapan pengembangan koleksi yang baik dan benar guna memenuhi kebutuhan informasi pemustaka. Sedangkan, untuk kompetensi pustakawan Open Library sendiri telah mencakup aspek kompetensi pustakawan berdasarkan Peraturan Pemerintah Nomor 24 Tahun 2014 tentang Pelaksanaan Undang-undang Nomor 43 Tahun 2007 tentang Perpustakaan, Pasal 34 menyatakan bahwa pustakawan harus memiliki (1) kompetensi profesional dan (2) kompetensi 
personal. Kompetensi profesional sendiri mencakup aspek pengetahuan, keahlian dan sikap kerja. Sedangkan, kompetensi personal mencakup aspek kepribadian dan interaksi sosial.

\begin{tabular}{|l|l|l|l|l|}
\hline $\begin{array}{l}\text { Sub } \\
\text { Variabel }\end{array}$ & $\boldsymbol{\rho}$ & $\mathbf{t}_{\text {hitung }}$ & $\begin{array}{l}\mathbf{t}_{\text {tabe }} \\
\mathbf{1}\end{array}$ & $\begin{array}{l}\text { Keputusa } \\
\mathbf{n}\end{array}$ \\
\hline Hubungan & 0,82 & 14,5 & 1,6 & $\mathrm{H}_{1}$ \\
Ketersediaa & 6 & 2 & 6 & Diterima \\
n Koleksi & & & & \\
dan & & & & \\
Kompetensi & & & & \\
Pustakawan & & & & \\
dengan & & & & \\
Kepuasan & & & & \\
$\begin{array}{l}\text { Pemustaka } \\
\text { di Open }\end{array}$ & & & & \\
Library & & & & \\
Telkom & & & & \\
University & & & & \\
\hline
\end{tabular}

\section{Simpulan}

Berdasarkan hasil penelitian yang telah peneliti lakukan dan diuraikan pada bab sebelumnya, maka dapat ditarik kesimpulan sebagai berikut:

a. Ketersediaan koleksi memiliki hubungan yang kuat terhadap kepuasan pemustaka di Open Library Telkom University. Hal tersebut karena koleksi yang tersedia di Open Library telah memenuhi asas-asas dari pengembangan koleksi. Terpenuhinya relevansi, kelengkapan, kemutakhiran, dan keragaman koleksi dalam kebijakan pengembangan koleksi tersebut berdampak pada kuantitas dan kualitas ketersediaan koleksi bagi pemustaka Open Library yaitu kalangan mahasiswa. Koleksi yang tersediapun memberikan kebutuhan informasi yang dibutuhkan oleh pemustaka sehingga oleh beberapa menganggap ketersediaan koleksi Open Library memberikan kepuasan bagi pemustaka.

b. Kompetensi pustakawan memiliki hubungan yang kuat terhadap kepuasan pemustaka di Open Library Telkom University. Hal tersebut karena pustakawan Open Library memiliki kompetensi profesional untuk bidang mengolah informasi, memberikan pelayanan, dan mengelola perpustakaan. Pustakawan Open Library memiliki jenjang pendidikan terakhir ilmu perpustakaan merupakan nilai tambah bagi pemustaka serta aspek personal pustakawan yang menjadi attitude yang ditampilkan bagi pemustaka. Sehingga, pendapat oleh beberapa responden kompetensi pustakawan Open Library memadai.

c. Ketersediaan koleksi dan komperensi pustakawan dengan kepuasan pemustaka di Open Library Telkom University memiliki hubungan yang kuat. Hal ini karena ketersediaan koleksi telah mencakup 4 kebijakan koleksi yaitu kerelevanan, kelengkapan, kemutakhiran, dan keberagaman. Serta, kompetensi pustakawan yang telah mencakup 2 aspek kompetensi pustakawan yaitu kompetensi professional dan kompetensi personal. Keduanya telah memenuhi semua aspek yang ada didalamnya. Hal itu berdampak pada bertambahnya nilai dan citra Open Library dan memberikan kepuasan pada pemustaka.

\section{Daftar Pustaka}

Basuki, S. (1991). Pengantar Ilmu Perpustakaan. Jakarta: Gramedia Pustaka Utama.

Hawalmy, Rafky. (2017). Tanggan Pemustaka Terhadap Ketersediaan Koleksi di Perpustakaan. Universitas Padjadjaran.

Irawan, H. (2002). 10 Prinsip Kepuasan Pelanggan. Jakarta: Elek Media Komputindo.

Kirom, B. (2015). Mengukur Kinerja Pelayanan dan Kepuasan Konsumen. Bandung: Pustaka Reka Cipta.

Peraturan Pemerintah Nomor 24 Tahun 2014 tentang Pelaksanaan Undang-undang Nomor 43 Tahun 2007 tentang Perpustakaan, Pasal 34

Prijana, Winoto, Y., \& Yanto, A. (2016). Metode Penelitian Kuantitatif. Bandung: Unpad Press.

Sugiyono (2014). Metode Penelitian Kuantitatif, Kualitatif, dan R\&D. Bandung: Alfabeta. 